\title{
Case Studies for Clean Technology Development in the Chemical Industry Using Zeolite Based Catalysts
}

\author{
Tatjána Juzsakova ${ }^{1}$, Noor Al-Jammal ${ }^{1}$, Igor Cretescu ${ }^{2, *} \mathbb{1}$, Viktor Sebestyén ${ }^{1}$, \\ Cuong Le Phuoc ${ }^{3}{ }^{\circledR}$, Endre Domokos ${ }^{1}$, Ákos Rédey ${ }^{1}$ and Catalina Daniela Stan ${ }^{4}$ \\ 1 Institute of Environmental Engineering, University of Pannonia, Veszprem, 10 Egyetem St., \\ 8200 Veszprém, Hungary; yuzhakova@almos.uni-pannon.hu (T.J.); \\ noor_aljmmal_1986@hotmail.com (N.A.-J.); sebestyen.viktor88@gmail.com (V.S.); \\ drdomokosendre@gmail.com (E.D.); redey.akos@gmail.com (Á.R.) \\ 2 Faculty Chemical Engineering and Environmental Protection, "Gheorghe Asachi" Technical University of \\ Iasi, D. Mangeron 73, 700050 Iasi, Romania \\ 3 Department of Environmental Management, Faculty of Environment, The University of Danang-University \\ of Science and Technology, 54 Nguyen Luong Bang street, Lien Chieu District, Danang 550000, Vietnam; \\ lpcuong@dut.udn.vn \\ 4 Department of Drug Industry and Pharmaceutical Biotechnology, “Grigore T. Popa” University of Medicine \\ and Pharmacy, 16 University St., 700115 Iasi, Romania; catalinastan68@yahoo.com \\ * Correspondence: icre@tuisi.ro; Tel.: +40-741-914-342
}

Received: 11 September 2018; Accepted: 12 October 2018; Published: 17 October 2018

\begin{abstract}
This paper deals with the practical implementation of cleaner technologies in the chemical industry, using two case studies as an illustration. The first case study deals with the removal of NOx and $\mathrm{N}_{2} \mathrm{O}$ gases over an iron-doped ZSM- 5 catalyst developed for tail gas treatment in nitric acid manufacturing. The aim for this case study was to investigate the efficiency of the zeolitic catalyst in the DeNOx process and to compare its catalytic activity with the conventional vanadia-titania. By the experiments carried out, it can be concluded that the new technological developments could significantly contribute to a decrease in environmental pollution. The second case study focuses on zeolite-based catalysts prepared from zeolitic tuff by the impregnation method, for biodiesel production from waste sunflower vegetable oil. The effects of operating and processing variables such as reaction temperature and time were investigated. The results showed that the highest biodiesel yield was $96.7 \%$ at an $11.5 \mathrm{MeOH} /$ oil molar ratio, in the presence of $6.4 \mathrm{wt} \%$ catalyst at a $50{ }^{\circ} \mathrm{C}$ reaction temperature and reaction time of $2 \mathrm{~h}$. The properties of the biodiesel that was produced, such as the viscosity, meet the required specifications of standard JUS EN14214. The common feature of the two different case studies is that both technologies use zeolite catalysts, namely naturally-occurring zeolitic tuff and synthetic ZSM type zeolite catalyst. The examples shown emphasize the importance of the zeolites in clean chemical technologies, which contribute to the protection of the environment.
\end{abstract}

Keywords: nitrogen oxide emission; SCR; DeNOx; tail gas treatment; biodiesel; transesterification of waste vegetable oil

\section{Introduction}

Cleaner production and other preventive initiatives, such as eco-auditing and green technologies, are the main measures being used to advance sustainable development in the industrial sector. Cleaner production could be applied in the chemical industry by using an integrated strategy for environmental protection and pollution prevention. This strategy would need to be focused on processes 
(conservation of energy and raw materials, elimination of toxic compounds and reducing emissions, byproducts and waste) [1].

Even if it is well known that the chemical industry is not the highest industrial polluter, its public perception is still unfavorable (especially the inorganic high tonnage industries, such as the production of sulfuric/nitric/phosphoric acid, ammonia, caustic soda, fertilizers, and so forth), due to the toxicity of emissions, products, byproducts, waste and raw materials. To change this perception, many studies with industrial applications have been published (i.e., obtaining calcium carbonate by a new technological approach, namely through Asahi Glass technology). This clean technology consists of the conversion of ammonia chloride into calcium chloride by its dissolution with lime. The obtained ammonia is recycled in the gaseous phase, and the solution of calcium chloride is processed by physical treatments, being transformed into products required on the market and simultaneously solving an environmental issue related to the management of technological residual solutions [2].

Clean technologies can be interpreted as procedures, processes and products that mitigate or eliminate the detrimental or hazardous environmental impacts by the use of technological developments, introduction of environmentally-friendly processes, savings in the use of natural resources like water, energy carriers and raw materials and by reducing discharge into the environment [3,4]. Clean technology covers a wide palette of technologies related to recycling, reuse, reproduction and use of renewable energy (ocean energy, wind power, solar power, biomass utilization, hydropower, etc.) $[4,5]$. Projects devised with the objective to eliminate the contribution to climate change (e.g., the Kyoto Clean Development Mechanism project) [6] are referred to as zero-carbon projects. However, it should be noted that there is no uniform definition of "clean technology". It can be defined as a wide range of products, services and procedures that use renewable/recycled materials and alternative energy sources and significantly decrease the exploitation of resources and mitigate or eliminate emissions and waste. Clean technology is a very important tool to contribute to and efficiently support the implementation of the objectives of sustainable development [7].

"Sustainable development" can be defined as development that meets the needs of the present without compromising future generations [8]. The expected result of sustainable development is a society where the quality of life and the use of natural resources meet human needs without jeopardizing natural systems [9]. Three essential elements of sustainable development are environmental protection, social development and economic growth. The concept of sustainable development has been questioned recently [10]. Some scientists argue that the expression of tolerable or endurable development would be better since, in light of the growing population and economic output, the present nature of development cannot be maintained in the future.

In the chemical industry, clean technological processes have a positive impact on local, regional and global environmental issues [11]. The chemical industrial sector includes companies that produce industrial and fine chemicals. The chemical industry converts raw materials (oil, natural gas, air, water, metals and minerals) into more than 70,000 different products used in our daily life [12]. Inorganic chemicals include ammonia, different fertilizers, chlorine, caustic soda and acids (such as nitric acid, phosphoric acid and sulfuric acid). Fertilizers include ammonium nitrate, phosphates and potash chemicals. The companies manufacturing and marketing chemical products give top priority to the protection of the environment [13], e.g., Pet Nitrogénmúvek Zrt. Company, a nitrogen fertilizer manufacturing company in Hungary [14] and Royal Dutch Shell oil and gas company [15]. To decrease the detrimental environmental impacts on air, water and soil, environmental programs and actions have been commenced by most companies, which mostly focus on production technology and environmentally-friendly product development. In many cases, the goals of the sustainable industrial development can be realized by catalytic processes. Zeolites have found promising application in biomass conversion, fuel cells, thermal energy storage, carbon dioxide adsorption, air pollution control and wastewater treatment [16]. The chemical industrial companies have been operating in light of the environmental stipulations of the European Union and the requirement to meet the pertaining legal environmental regulations. The pollution impact assessment is usually measured using the index of 
global pollution (IGP), which takes into consideration quality indicators from the main environmental components (air, water and soil) [17] or, according to the most recent assessment method, at least two environmental components should be taken into consideration [18].

\subsection{Nitrogen Oxides Emission}

Nitrogen oxides $\left(\mathrm{NO}, \mathrm{NO}_{2}, \mathrm{~N}_{2} \mathrm{O}\right)$ are considered to be major pollutants in the atmosphere and result in acid rain, photochemical smog and ozone accumulation [19]. Furthermore, these oxides are corrosive and hazardous to health. Similarly to the EU statistics, the main anthropogenic nitrogen oxides sources in Hungary are the public electricity and heat sector $(43 \%)$, transportation $(44 \%)$, agriculture $(10 \%)$ and industrial processes $(2 \%)$ [20]. The emission limit for nitrogen oxides (set for $\mathrm{NO}_{2}$ ) is $350 \mathrm{mg} / \mathrm{m}^{3}$ in dry tail gases at $0{ }^{\circ} \mathrm{C}$ and $101.3 \mathrm{kPa}$ in the case of nitric acid production [21].

In terms of being the most detrimental nitrogen oxides sources, the following activities have been identified not only strictly considering the chemical industry [22]:

- Combustion of fuels: At high temperatures, the oxygen and nitrogen content of the air forms nitrogen oxides. Typical flue gas contains about 100-1500 ppm of nitrogen oxides.

- Nitric acid production in fertilizer manufacturing technology: Stack gases that cannot be absorbed usually contain $2-3 \%$ nitrogen oxides relative to the acid produced.

- Metal finishing operations: Several metal surface treatment procedures use nitrates, nitrites or nitric acid, which generate nitrogen oxides.

- Chemical processes: Many chemical technologies (explosives, plastics, nitrated materials, etc.) that use nitric acid, nitrates or nitrites result in the formation of nitrogen oxides. Cement kilns, glass manufacturers and power generating plants (where high processing temperatures are used) also produce NOx.

- Agriculture: Biochemical processes result in the generation of nitrous oxide in soils during nitrification, denitrification and decomposition of nitrogen compounds in livestock manure [23].

\subsection{Biodiesel}

Biodiesel is a renewable fuel that is manufactured from sustainable feed stocks such as vegetable oil, soybean oil, jatropha oil, sunflower oil and rapeseed oil, as well as other fats, by various methods [24]. Waste and/or virgin vegetable oils represent a promising raw material for biodiesel production via the transesterification of triglycerides of oils using alcohol, in the presence of a catalyst $[25,26]$. In the transesterification reaction, alcohol is reacted with triglycerides using the catalyst to result in fatty acid esters and glycerin. However, economic limitations have been one of the major barriers in biodiesel production. Therefore, reducing biodiesel production cost is the primary focus in order to commercialize biodiesel products. Fukuda and other researchers [27-29] have stated that the biodiesel production cost depends on the cost of raw materials; this contributes $70-85 \%$ of the total biodiesel production cost, given that the cost of feedstock for biodiesel production is more expensive than conventional diesel fuel.

Accordingly, choosing inexpensive and easily available biomass feedstock such as non-edible oils, fried waste oils and animal fats can decrease the total production costs and enable a more environmentally-friendly biodiesel production process [30]. Significant amounts of used cooking oils and waste animal fats are being dumped all over the world. The disposal of such oils and fats poses a significant challenge due to environmental problems. Additionally, a catalyst is needed to promote the transesterification reaction [31]. Haas and Foglia reported that the effect of a catalyst is pronounced, as it contributes to $30-35 \%$ of the production cost [32].

Consequently, the type of catalyst used in biodiesel production is an important issue. A very large number of potentially useful catalysts have been used to accelerate the rate of transesterification of oils, including enzymatic bio-catalysts [33] and homogeneous and heterogeneous acid or base catalysts. Industrial water management in the chemical industry is an important aspect that should be taken 
into consideration, due to the huge amount of water needed for both technological water and process water [34].

The main aim of the clean technologies presented in both study cases is related to the upgrading of the process and pollution prevention, to diminish the pollution level and improve the recycling of the waste products, making possible an important economy of fossil resources.

\section{Materials and Methods}

The main objective of these two case studies is to investigate the efficiency of catalytic processes (zeolite catalyzed processes) to achieve higher yields in nitric acid and biodiesel production with the minimum level in environmental pollution while meeting the required specifications of the standards.

Zeolites are microporous, aluminosilicate minerals generally used as commercial adsorbents and catalysts. Zeolites occur naturally, but are also produced industrially on a large scale. Zeolites are a significant class of natural and synthetic hydrated aluminum silicates. The zeolites can be described by sophisticated three-dimensional structures, which form cages and cavities. The atomic structures of zeolites are based on three-dimensional frameworks of silica and alumina-centered tetrahedra surrounded by four oxygen ions at the corners. Clusters of tetrahedra can form different units that are further linked to constitute the entire framework. However, it is common that the primary building units in the naturally-occurring zeolites and the synthetic zeolites is the silica and alumina tetrahedral.

\subsection{Selective Catalytic Reduction of Nitrogen Oxides with Ammonia}

The goal of the work was to investigate the morphological properties of the conventional vanadium oxide-titania $\left(\mathrm{V}_{2} \mathrm{O}_{5} / \mathrm{TiO}_{2}\right)$ and iron doped zeolite (Fe-ZSM-5) commercial catalysts and to study the catalytic activities shown in the selective catalytic reduction (SCR) of nitrogen oxides with ammonia. The purity of the ammonia supplied by Messer Ltd. (Bath, UK) was 99.98\%, and the purity of NOx gases prepared by the authors by burning ammonia was $99.90 \%$. The vanadia-titania type catalyst was supplied by Mitsubishi Chemical Industries Co. (Tokyo, Japan), and the iron-doped zeolite catalyst was provided by Süd-Chemie Co. (Munich, Germany). The $\mathrm{V}_{2} \mathrm{O}_{5} / \mathrm{TiO}_{2}$ catalyst of spherical form, with a $3 \mathrm{~mm}$ diameter, contained $10 \mathrm{wt} \%$ vanadia on titania (anatase). The Fe-ZSM-5 zeolite catalyst with a rod shape of 3-10 mm contained $0.67 \mathrm{wt} \% \mathrm{Fe}$ and had a Si $/ \mathrm{Al}=31.3$ ratio [35]. The morphological features of the catalysts were studied by low temperature nitrogen adsorption (BET). The specific surface areas, pore volumes and pore sizes in the micropore (1.7-2 nm), mesopore $(2-50 \mathrm{~nm})$ and the macropore $(50-100 \mathrm{~nm})$ ranges of the catalyst samples were determined by nitrogen adsorption/desorption isotherms, measured with a Micromeritics ASAP 2000-Type Instrument (Micromeritics Instrument Corporation, Norcross, GA, USA) on samples (weight $\sim 1.0 \mathrm{~g}$ ) previously outgassed in a vacuum at $160{ }^{\circ} \mathrm{C}$. The surface areas and the pore volume values were calculated from the nitrogen adsorption-desorption isotherms using standard methods.

The crystalline structure of the samples was investigated using the X-ray diffraction technique (XRD). The XRD patterns were recorded at room temperature over a $4-70^{\circ} 2 \theta$ angular range by a Philips PW3710 diffractometer (Philips, Eindhoven, The Netherlands) equipped with a CuK $\alpha$ source $(\lambda=1.5406 \AA)$ and operated at $50 \mathrm{kV}, 40 \mathrm{~mA}$. The samples were measured in continuous scan mode with a $0.02^{\circ} / \mathrm{s}$ scanning speed.

The effect of the technological parameters (reaction temperature and $\mathrm{NH}_{3} / \mathrm{NOx}$ ratio) on the $\mathrm{NO}$ and $\mathrm{NO}_{2}$ reduction (DeNOx reaction) was also studied. The reaction temperature range was 200-450 ${ }^{\circ} \mathrm{C}$; the $\mathrm{NH}_{3} / \mathrm{NOx}$ feed ratios were $0.9,1.2,1.6$ and 2.2; the inlet NOx concentration was $\mathrm{C}_{\mathrm{NOx}}$ average $=4800 \mathrm{ppm}$; and the inlet ammonia concentration was $\mathrm{C}_{\mathrm{NH} 3}=4484(5970,7451$ and 10,400) ppm. The plug flow reactor, with a loading of $80 \mathrm{~cm}^{3}$ of the catalyst and supported on quartz chips, was used for the experiments. The experimental system was equipped with mass flow controllers, a preheater, a temperature controller and a cooler, as is typical for catalytic systems. The exit gases (NO, NOx) were analyzed by a non-dispersive infrared instrument (NDIR) (UNOR 6N/convector HI 50 N, Maihak Co., Hamburg, Germany). 


\subsection{Biodiesel Production}

In the case of biodiesel production, a series of transesterification reaction was performed. Four different reaction temperatures were selected for the experiments: $30,40,50$ and $60{ }^{\circ} \mathrm{C}$. The stirring speed ranged between 200 and $1200 \mathrm{rpm}$, and the particle size of the catalyst varied between 125 and $500 \mu \mathrm{m}$. The amount of catalyst was 2.1,4.3 and $6.4 \mathrm{wt} \%$ at a methanol-oil molar ratio of 11.5 . The reaction time was between 1 and $5 \mathrm{~h}$. The vegetable oil conversion was calculated as the amount of the converted vegetable oil related to the vegetable oil fed. The biodiesel yield was defined as the ratio of the mass of biodiesel formed to the mass of initial oil feedstock.

The reactant waste vegetable (sunflower) oil (WVO) was collected from the University of Jordan restaurant. The zeolitic tuff was obtained from the Jordanian Natural Resources Authority (NRA), after being collected from the Jabal-Aritayn site (30 km northeast of Azraq) south of Jordan [36]. Analytical-grade hydrochloric acid $(\mathrm{HCl}, 37 \%)$, potassium hydroxide $(\mathrm{KOH}, 90 \%)$ and methanol $(99.5 \%)$ were used. All chemicals in this work were obtained from the Gulf Coast Company (GCC).

The analytical methods and/or devices used for the characterization of the WVO and the produced biodiesel were carried out according to international standards [37,38]. All tests were repeated up to three times, and the averaged values were adopted. A Varian 3300 chromatograph equipped with FID (Varian, Inc., Walnut Creek, CA, USA) was used to determine and quantify all the individual components of the used oil (fatty acid distribution). Chromatographic separation was achieved by a 15\% OV-275 on Chromosorb WAW, 80/100 mesh, 2-m length, 3.17-mm outside diameter, stainless steel column type.

The influences of different parameters on the WVO conversion and biodiesel yield were investigated as a function of the reaction temperature. Conversion tests [39] were implemented to follow the changes in the biodiesel yield. The biodiesel (methyl ester) dissolves easily in methanol, forming a clear bright phase, while vegetable or animal oils and fats (triglycerides) do not dissolve in methanol $[39,40]$. However, monoglycerides and diglycerides (partly converted vegetable oil) are partially soluble.

The mass fractions for the individual components of the waste vegetable oil were obtained from the gas chromatographic analysis. The vegetable oil used for the experiments was mainly composed of $57.1 \mathrm{wt} \%$ linoleic acid and $28.2 \mathrm{wt} \%$ oleic acid. Other saturated fatty acids that were utilized included palmitic and stearic acids.

\section{Results}

\subsection{Results of the DeNOx Tests}

\subsubsection{Structural Properties of the Catalysts}

The features of the catalysts studied in the DeNOx reaction were mainly studied by the XRD and BET techniques. Samples were investigated before and after the catalytic tests. In its freshly-prepared form, it had a surface area, $S_{\mathrm{BET}}$, of $39 \mathrm{~m}^{2} / \mathrm{g}$, an average pore diameter, $\mathrm{D}_{\mathrm{av}}$, of $18 \mathrm{~nm}$, and a pore volume, $\mathrm{V}$, of $0.2149 \mathrm{~cm}^{3} / \mathrm{g}$ (Table 1$) . \mathrm{V}_{2} \mathrm{O}_{5} / \mathrm{TiO}_{2}$ micropores $(<2 \mathrm{~nm}$ ) contributed $5 \%$ to the total surface area. Changes were observed in the morphology of the $\mathrm{V}_{2} \mathrm{O}_{5} / \mathrm{TiO}_{2}$ catalyst after the DeNOx catalytic tests. The specific surface area and pore volume decreased to $35 \mathrm{~m}^{2} / \mathrm{g}$ and $0.2101 \mathrm{~cm}^{3} / \mathrm{g}$, respectively.

Table 1. Total and micropore surface areas, $\mathrm{S}_{\mathrm{BET}}$ and $\mathrm{S}_{\text {micro, }}$, total and microporous pore volumes, $\mathrm{V}$ and $\mathrm{V}_{\text {micro, }}$ average pore size, $\mathrm{D}_{\mathrm{av}}$, and values of fresh and used catalysts.

\begin{tabular}{cccccc}
\hline Sample & $\mathbf{S}_{\text {BET }}, \mathbf{~ m}^{\mathbf{2}} \mathbf{g}$ & $\mathbf{S}_{\text {micro, }} \mathbf{~ m}^{\mathbf{2}} \mathbf{g}$ & $\mathbf{V}, \mathbf{c m}^{\mathbf{3}} / \mathbf{g}$ & $\mathbf{V}_{\text {micro, }} \mathbf{c m}^{\mathbf{2}} \mathbf{g}$ & $\mathbf{D}_{\mathbf{a v}}, \mathbf{n m}$ \\
\hline $\mathrm{V}_{2} \mathrm{O}_{5} / \mathrm{TiO}_{2}$ fresh & 39 & 2.0 & 0.2149 & 0.00062 & 18.2 \\
$\mathrm{~V}_{2} \mathrm{O}_{5} / \mathrm{TiO}_{2}$ used & 35 & 2.4 & 0.2101 & 0.00080 & 20.0 \\
$\mathrm{Fe}-\mathrm{ZSM}-5$ fresh & 311 & 194.7 & 0.1737 & 0.09050 & 6.3 \\
$\mathrm{Fe}-Z S M-5$ used & 312 & 195.2 & 0.1744 & 0.09127 & 6.7 \\
\hline
\end{tabular}


Its surface area in the fresh form was eight-times higher $\left(311 \mathrm{~m}^{2} / \mathrm{g}\right)$ than that of the vanadia catalyst, with an average pore diameter of $6.3 \mathrm{~nm}$ (Table 1).

The XRD results showed that the $\mathrm{V}_{2} \mathrm{O}_{5} / \mathrm{TiO}_{2}$ catalyst had an anatase crystalline structure. Furthermore, a small amount of barite $\left(\mathrm{BaSO}_{4}\right)$ was observed. After the catalytic test, no modification of the crystalline structure from anatase to rutile occurred. The Fe-ZSM- 5 fresh sample contained hematite $\left(\mathrm{Fe}_{2} \mathrm{O}_{3}\right)$ and crystalline zeolite. The structure of the catalyst was preserved after the DeNOx tests.

\subsubsection{Catalytic Tests}

The practical realization of cleaner technologies is a possible solution for the present air pollution problems, with a special focus on the reduction of nitrogen oxide $\mathrm{NO}, \mathrm{NO}_{2}$ and $\mathrm{N}_{2} \mathrm{O}$ discharges in industrial processes. Regarding the removal of nitrogen oxides, the selective catalytic reduction (SCR) and the non-selective catalytic reduction (NSCR) can be taken into consideration [41]. By using catalytic converters on automobiles, the mobile NOx emissions have been drastically decreased in gasoline- and diesel-operated vehicles.

The process flow diagram of the nitric acid production is illustrated in Figure 1. This process utilizes a tail gas reactor installed after the absorber and before the tail gas expander (turbine) [42].

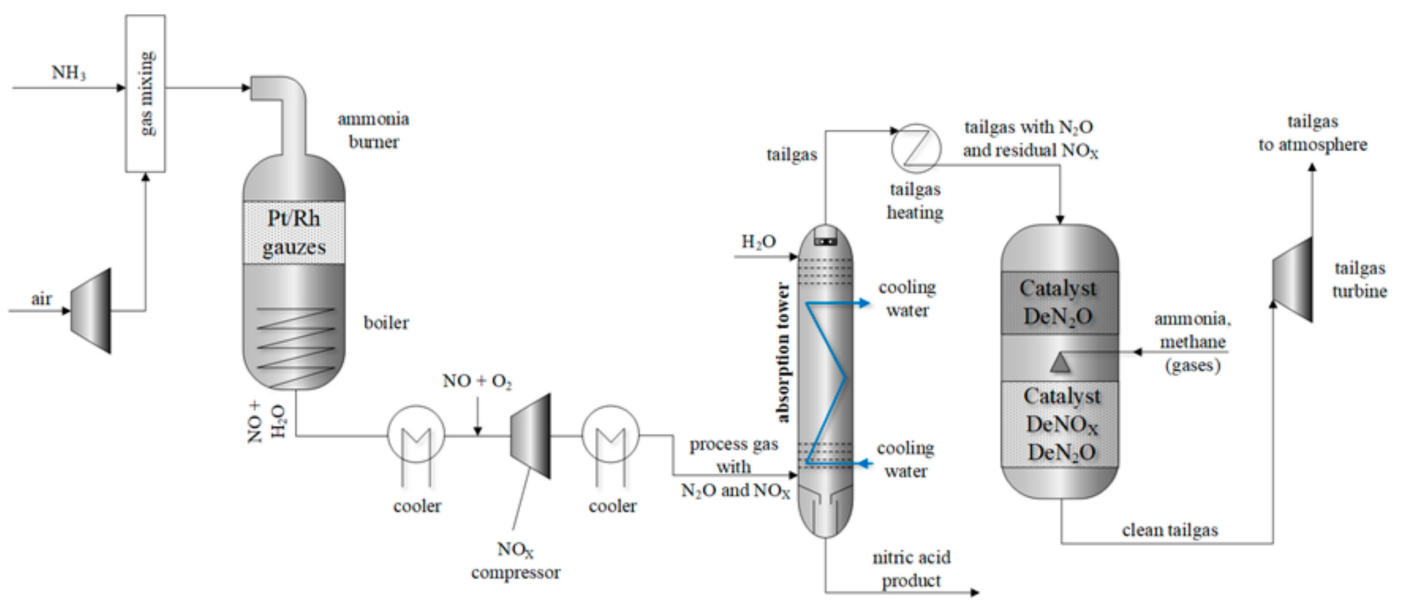

Figure 1. Nitric acid production and tail gas treatment.

Improvements regarding reduction of the nitrogen oxide emissions can be realized by devising efficient catalysts for the decomposition of $\mathrm{NOx}$ and $\mathrm{N}_{2} \mathrm{O}[35,43]$. The best available technology (BAT) for tail gas treatment of nitric acid production is based on SCR and NSCR processes. The following chemical reactions take place during the SCR tail gas treatment:

$$
\begin{gathered}
4 \mathrm{NO}+4 \mathrm{NH}_{3}+\mathrm{O}_{2} \rightarrow 4 \mathrm{~N}_{2}+6 \mathrm{H}_{2} \mathrm{O} \\
6 \mathrm{NO}_{2}+8 \mathrm{NH}_{3} \rightarrow 7 \mathrm{~N}_{2}+12 \mathrm{H}_{2} \mathrm{O}
\end{gathered}
$$

During SCR, the NOx containing gases are introduced into the reactor and are mixed with ammonia [44]. The typical SCR industrial catalysts are $\mathrm{V}_{2} \mathrm{O}_{5} / \mathrm{TiO}_{2}$ and zeolite-based catalysts. The ZSM-5 catalysts are widely used in addition to the DeNOx processes, e.g., in the petroleum processing industry (fluid catalytic cracking, hydroisomerization, etc.) [45]. The outcome of the DeNOx process is the conversion of NOx compounds to nitrogen gas and water vapor, which can be released into the atmosphere.

In this work, the SCR of NOx was studied for the elimination of the detrimental pollutant discharges under conditions similar to the treatment of tail gases at a nitric acid plant. The conventional $\mathrm{V}_{2} \mathrm{O}_{5} / \mathrm{TiO}_{2}$ and Fe-ZSM-5 catalysts were studied. It is to be noted that both catalysts are not recommended to be used below $230{ }^{\circ} \mathrm{C}$. At low temperatures, the ammonia reacts with $\mathrm{NO}_{2}$, resulting in ammonium nitrate and ammonia nitrite and leading to clogging. 
The experimental results are depicted in Figures 2 and 3 for the two different catalysts. The studied SCR DeNOX catalysts showed different and relatively broad optimums of operation temperature. The Fe-ZSM-5 catalyst showed higher NOx conversion (97-98\%) at 290-320 ${ }^{\circ} \mathrm{C}$ at a $\mathrm{NH}_{3} / \mathrm{NOx} 1.6$ feed (Figure 1). At the highest $\mathrm{NH}_{3} / \mathrm{NOx}=2.2$ feed, the conversion was constantly near $98 \%$ in the temperature range that was studied. Feed ratios higher than 1:2.2 are to be avoided since unconverted $\mathrm{NH}_{3}$ can be measured at the outlet.

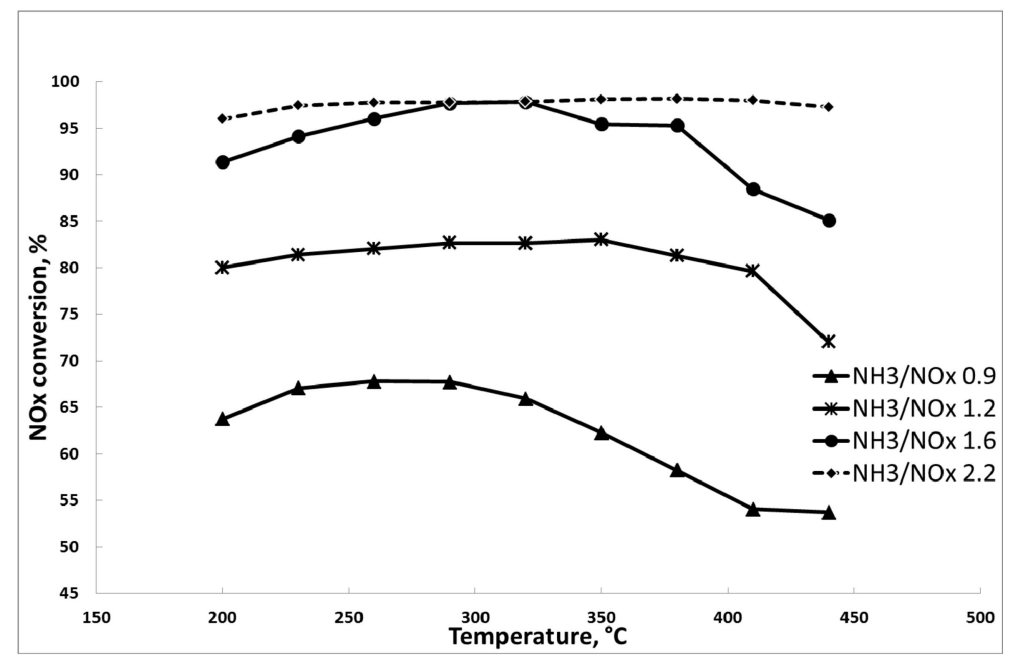

Figure 2. Effect of the temperature on $\mathrm{NOx}$ conversion at different $\mathrm{NH}_{3} / \mathrm{NOx}$ ratios for Fe-ZSM-5 catalysts.

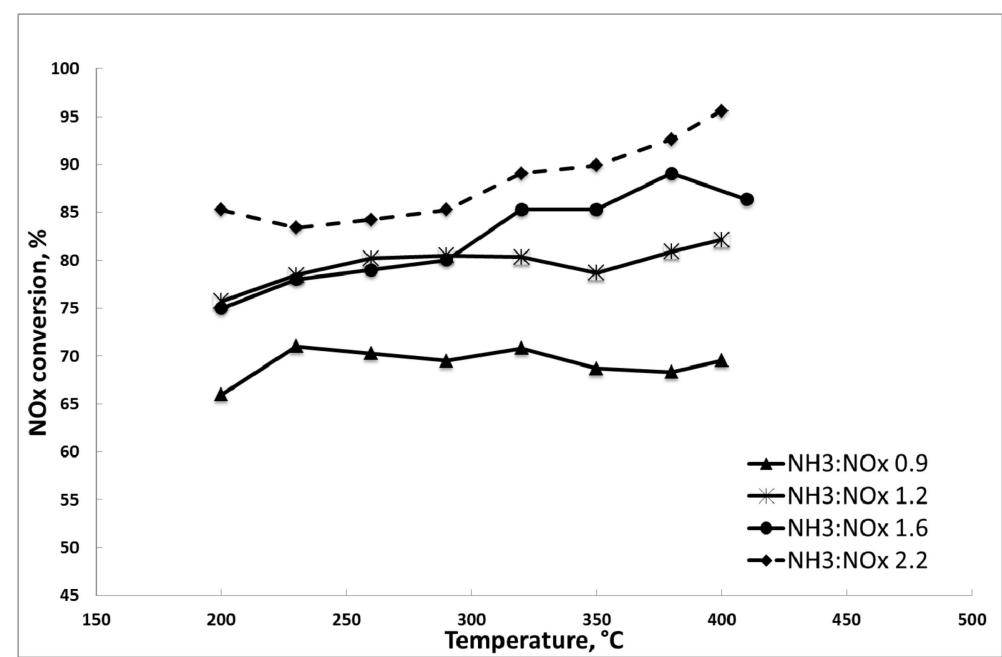

Figure 3. Effect of the temperature on $\mathrm{NOx}$ conversion at different $\mathrm{NH}_{3} / \mathrm{NOx}$ ratios for $\mathrm{V}_{2} \mathrm{O}_{5} / \mathrm{TiO}_{2}$ catalysts.

It can be seen in Figure 3 that under the same conditions $\left(\mathrm{T}=290-320^{\circ} \mathrm{C}\right.$ and $\mathrm{NH}_{3} / \mathrm{NOx}=1.6$ feed ratio), the conversion was lower $(\sim 82 \%)$ with the $\mathrm{V}_{2} \mathrm{O}_{5} / \mathrm{TiO}_{2} \mathrm{SCR}$ catalyst than the zeolite catalyst. The $\mathrm{V}_{2} \mathrm{O}_{5} / \mathrm{TiO}_{2}$ catalyst has high activity in the temperature range of $250-400{ }^{\circ} \mathrm{C}$. The maximum $\mathrm{NO}_{\mathrm{X}}$ conversion $(95 \%)$ was reached at $\mathrm{NH}_{3} / \mathrm{NO}_{\mathrm{X}}=2.2$ highest feed and temperature $\left(400{ }^{\circ} \mathrm{C}\right)$.

Zeolites are moderately high temperature-operating catalysts. They are stable up to $600{ }^{\circ} \mathrm{C}$ and are more environmentally friendly, since higher conversions can be achieved at the same reaction temperature and no toxic element such as vanadium can enter into the atmosphere. The recommended operation temperature range of the used commercial Fe-ZSM- 5 catalyst (DeNOx) is between $200{ }^{\circ} \mathrm{C}$ and $520^{\circ} \mathrm{C}$, with the optimum decomposition temperature for both nitrogen oxides and dinitrogen oxide around $420{ }^{\circ} \mathrm{C}$. The conversion rates are up to $98 \%[43,46,47]$. The $\mathrm{V}_{2} \mathrm{O}_{5} / \mathrm{TiO}_{2}$ catalyst is a 
medium temperature-operating catalyst $\left(300-450{ }^{\circ} \mathrm{C}\right)$, but the recommended temperature window is 300-400 ${ }^{\circ} \mathrm{C}$, since above this temperature, the catalyst loses its selectivity [41]. It is also to be noted that in spite of the fact that the specific surface area of the vanadia-alumina catalyst is 8-9 times lower than that of the zeolite catalyst, this does not show up in the activity/conversion differences of the two catalyst preparations. This difference can be due to the active sites and the strength of the active sites of the catalyst preparations. On the basis of the time on stream experiments, it can be stated that the zeolite-based catalyst can be used for a longer period of time of three weeks vs. one week without significant activity loss.

Based on the experiments carried out, it can be concluded that technological developments could significantly contribute to the reduction in environmental pollution and greenhouse gas discharge in industrial facilities.

\subsection{Biodiesel Production from Waste Vegetable Oil over Jordanian Zeolite as the Catalyst}

The influence of several technological parameters on the conversion of the transesterification reaction and the biodiesel yield was investigated. The measured kinematic viscosity of the used WVO was $39.4 \pm 0.20 \mathrm{~mm}^{2} / \mathrm{s}$ at $40{ }^{\circ} \mathrm{C}$, higher than the value reported in the literature [40] $\left(35.3 \mathrm{~mm}^{2} / \mathrm{s}\right.$ at $40{ }^{\circ} \mathrm{C}$ ). The test result for the acid value was found to be $2.01 \mathrm{mg} \mathrm{KOH} / \mathrm{g}$ for the WVO. The resulting acid value of the WVO was on the lower side compared to the maximum value recommended for oils to be used for biodiesel production by alkali transesterification. In the present study, the peroxide value of WVO was $13.02 \mathrm{mEq} \mathrm{O}_{2} / \mathrm{kg}$ oil; a lower peroxide value was measured for sunflower oil by Goering et al. [48], namely a $10.7 \mathrm{mEq} \mathrm{O}_{2} / \mathrm{kg}$ oil value was reported. For the biodiesel sample, the measured peroxide value was $44.38 \mathrm{mEq} \mathrm{O}_{2} / \mathrm{kg}$ biodiesel.

\subsubsection{Properties of the Zeolitic Tuff}

The zeolite catalyst was prepared from zeolitic tuff using two impregnation steps with heating encountered in the second step, according to the procedure described in the literature [36]. The analytical results (XRD) confirmed phillipsite, forsterite, chabazite, quartz, hematite and sanidine in the raw zeolitic tuff. The specific surface area of the raw zeolitic tuff was $77 \mathrm{~m}^{2} / \mathrm{g}$. The transesterification reaction was carried out using the prepared catalyst and according to the procedure described in the literature [36]. The preliminary results [36] showed that the $\mathrm{KOH}$-treated zeolitic tuff, hereinafter referred to as the treated zeolitic tuff (TZT) catalyst, had the highest activity, and therefore, the investigations presented in the current work refer only to this catalyst.

\subsubsection{Effect of Reaction Temperature}

The transesterification reaction was carried out using the prepared catalyst and according to the procedure described in the literature [36]. Transesterification can occur at different temperatures depending on the types of catalyst and alcohol used. However, high reaction temperatures accelerate the reaction kinetics (both transesterification and saponification reactions). The influence of reaction temperature on the conversion of WVO to biodiesel was investigated as a function of temperature. The results are shown in Figure 4, which depicts the effect of temperature on the WVO conversion at a $\mathrm{MeOH} / \mathrm{WVO}$ molar ratio of 11.5:1 and a catalyst amount of 2.1, 4.3 and $6.4 \mathrm{wt} \%$.

It was observed at a catalyst amount of 2.1 and $4.3 \mathrm{wt} \%$ that the conversion of WVO increased as a function of the reaction temperature. The increment of conversion was different depending on the amount of the catalyst that was used. The effect was more pronounced at higher catalyst amounts. In the case of a catalyst amount of $6.4 \mathrm{wt} \%$, by increasing the reaction temperature from $30-50{ }^{\circ} \mathrm{C}$, the conversion of waste vegetable oil increased from 35-100\%. By increasing the reaction temperature to $60{ }^{\circ} \mathrm{C}$, the oil conversion slightly decreased. 


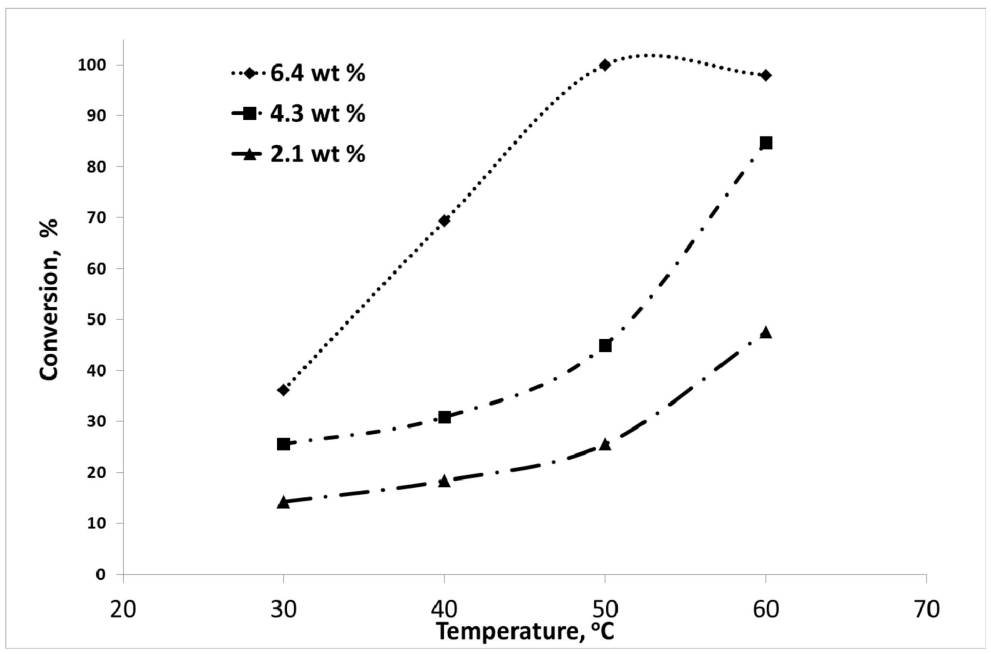

Figure 4. The effect of temperature on waste vegetable oil (WVO) conversion at the MeOH/WVO molar ratio of 11.5:1 in the presence of 2.1, 4.3 and $6.4 \mathrm{wt} \%$ of TZT catalyst, at temperatures of 30, 40, 50 and $60^{\circ} \mathrm{C}$.

The effect of reaction temperature on biodiesel yield is shown in Figure 5 for the temperature range of $30-60^{\circ} \mathrm{C}$ at $2 \mathrm{~h}$ reaction time and at 11.5:1 methanol/oil molar ratio. In the presence of higher amount of catalyst $(6.4 \mathrm{wt} \%)$, the biodiesel yield increased from $53.0-96.7 \%$ by increasing the temperature from $40-50{ }^{\circ} \mathrm{C}$ at $2 \mathrm{~h}$ of reaction time. The yield decreased to $77.8 \%$ at $60{ }^{\circ} \mathrm{C}$. Therefore, $50{ }^{\circ} \mathrm{C}$ was chosen as the optimum reaction temperature.

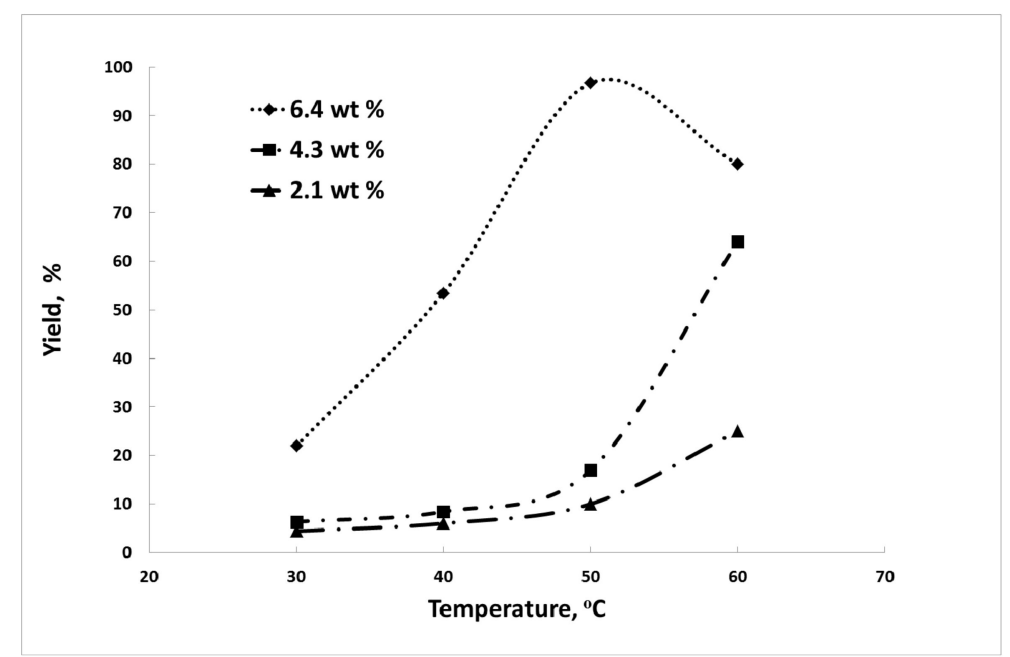

Figure 5. The effect of temperature on biodiesel yield at the $\mathrm{MeOH} / \mathrm{WVO}$ molar ratio of 11.5:1 in the presence of 2.1, 4.3 and $6.4 \mathrm{wt} \%$ TZT catalyst, at temperatures of $30,40,50$ and $60{ }^{\circ} \mathrm{C}$.

A significant difference in conversion values was observed when the amount of catalyst was increased from 2.1, to 4.3 , to $6.4 \mathrm{wt} \%$, and the temperature was changed. This can be explained by the mutual interaction between reaction parameters. It is worthy to mention here that Figures 4 and 5 prove the mutual interaction between the reaction temperature and catalyst weight and the effect of this interaction on biodiesel yield.

Such a kind of interaction among the reaction parameters was investigated by several studies [49]. The interactions between the catalyst concentration, reaction temperature and reaction time were significant regarding the biodiesel yield, and it was proven by the response surface methodology [49].

At higher reaction temperatures, there was a slight reduction in the biodiesel yield. It should be noted that a reaction temperature near or above the boiling point of alcohol will result in a yield 
decrease due to the fact that higher temperatures can accelerate the saponification reaction of glycerides before the completion of the alcoholysis. These results are in agreement with previous reported work $[40,50,51]$.

In the case of catalyst amounts of $2.1 \mathrm{wt} \%$ and $4.3 \mathrm{wt} \%$, the biodiesel yield continuously increased with increasing temperatures in the studied temperature range. This might be due to the catalyst loading (weight) accelerating the desired reaction. The optimized reaction temperature for the transesterification reaction obtained by previous studies was higher than the value found in this study. For example, $\mathrm{NaX}$ zeolite loaded with $\mathrm{KOH}$ was used as the base heterogeneous catalyst for the transesterification reaction, and the achieved conversion was $85.6 \%$ at $120{ }^{\circ} \mathrm{C}$ at a reaction time of $8 \mathrm{~h}$ [52]. In fact, limited studies have been conducted to investigate catalyst performance at temperatures lower than $70^{\circ} \mathrm{C}[53]$.

\section{Discussion on Sustainability Issues}

Global anthropogenic non- $\mathrm{CO}_{2}$ emissions are estimated to reach nearly 13,000 $\mathrm{Mt} \mathrm{CO}_{2 \text { eq }}$ by 2020 . However, mitigation actions are being explored in order to further decrease emissions. Nitrous oxide emissions have increased from $2871 \mathrm{MtCO}_{2 \text { eq }}$ continuously from 1990, to a predicted $4057 \mathrm{Mt} \mathrm{CO}_{2 \mathrm{eq}}$ by 2020. Certain public and industrial activities have increased recently (industrial production, communal wastes, energy generation, transportation, etc.); however, other factors have decreased the rate of growth in emissions. These include, for example, changes in the pattern of road transportation (electric cars), use of alternative energies, introduction of clean technologies, the green company concept, and so forth. For example, in Hungary, agricultural policies have resulted in more efficient farming practices and decreased the use of fertilizer. In spite of the results achieved, it is essential to initiate new programs in every sectoral division.

In order to implement effective environmental measures and operate a system efficiently according to the pertaining environmental regulations and stipulations, it is advised to follow the basic steps of the ISO14001 and 14004 standards, or those of the EAMS III. Therefore, it is necessary to have a full understanding of the environmental implications of daily business along with the environmental policy of the organization/company. By having a full picture of how the operations and business are undertaken, it is possible to identify how to improve operational efficiency, to mitigate the detrimental environmental impacts (in the present case to reduce the hazardous $\mathrm{NOx}$ and $\mathrm{N}_{2} \mathrm{O}$ discharges), to protect the environment and to decrease the costs (environmental fees and taxes) in order to improve the financial situation of the company.

Increasingly, companies and organizations are aware of the fact that environmentally-friendly operation is a core management issue and not just a matter of compliance with regulations. The EMS is a systematic approach to mitigate environmental impacts. Organizations undertake a commitment to continuous environmental improvement; therefore, the decrease of $\mathrm{NOx}$ and $\mathrm{N}_{2} \mathrm{O}$ emissions is a top priority in environmental programs.

According to the results described earlier, the highest (95\%) NOx conversion in tail gas treatment is similar to that of nitric acid manufacturing and was reached at a $400{ }^{\circ} \mathrm{C}$ reaction temperature at a $\mathrm{NH}_{3} / \mathrm{NO}_{\mathrm{X}} 2.2$ feed ratio for the $\mathrm{V}_{2} \mathrm{O}_{5} / \mathrm{TiO}_{2}$ catalyst. The iron-doped zeolite catalyst was active in SRC DeNOx in the temperature range of $290-320{ }^{\circ} \mathrm{C}$ and at lower $\mathrm{NH}_{3} / \mathrm{NO}_{X} 1.6$ feed ratio. It is advisable to avoid feed ratios higher than 1.5 since it results in significant ammonia slip (unconverted $\mathrm{NH}_{3}$ ) [41] . At preferable reaction gas feed $\left(\mathrm{NH}_{3}: \mathrm{NOx}=1.6\right)$, the conversion is only about $85 \%$ over $\mathrm{V}_{2} \mathrm{O}_{5} / \mathrm{TiO}_{2}$.

The concentration of $\mathrm{N}_{2} \mathrm{O}$ emission after catalytic treatment reduced from $\sim 1400$ ppmv to $<30$ ppmv, and the $\mathrm{N}_{2} \mathrm{O}$ outlet concentration was lower than 80 ppmv [46]. This could mean a potentially significant annual NOx and $\mathrm{N}_{2} \mathrm{O}$ reduction in greenhouse gas emission. The market pricing of $1 \mathrm{t}$ of carbon dioxide is about 7-15 EUR [54]. An emission decrease at the industrial level is a good step towards the accomplishment of the concept of sustainable development. More and more companies are following this strategy, and hopefully, this will contribute to decreasing the impacts of global environmental problems in the future. 
The influence of the operating parameters and conditions on the conversion of waste vegetable oil to biodiesel using zeolite-based heterogeneous catalysts was investigated. These parameters included the reaction temperatures, amount of catalyst and reaction time. Additionally, the properties of the produced biodiesel were investigated. The optimal yield of biodiesel was achieved with a $\mathrm{MeOH} / \mathrm{oil}$ molar ratio of 11.5 , a catalyst amount of $6.4 \mathrm{wt} \%$ and at $50{ }^{\circ} \mathrm{C}$ reaction temperature. A biodiesel yield of approximately $96.7 \%$ was achieved when the reaction time was adjusted to $2 \mathrm{~h}$. By studying the chemical and physical properties of the produced biodiesel, it was proven that these properties fulfill the requirements specified by the JUS EN14214 and ASTM [55,56] standards for biodiesel.

This topic is especially important in the case of countries like Jordan, where petroleum and natural gas resources are scarce. Therefore, alternative resources to produce fuels like diesel fuel are especially important to provide additional and renewable feed for the diesel pool. Since Jordan has abundant vegetable oil production and the used vegetable oil can be considered a valuable secondary raw material, the processing and utilization of this waste are especially important to supplement the existing natural resources.

\section{Conclusions}

The naturally-occurring zeolites and the synthetic zeolites can be efficiently used in several chemical processes, including the applications shown in this paper.

Sustainable production and consumption are important issues in the 21st Century, since human society is faced with decreasing availability of natural resources like energy carriers, clean water and depletion of soil. Therefore, special attention should to be paid to preserving the environment, to mitigating environmental pollution and to finding new possible alternative routes to substitute a fraction of the fuel demand with renewable and inexpensive energy carriers. This paper presented two case studies in the field of clean technologies with applications in the chemical industry, with the objective of contributing to the implementation of the goals of sustainable development:

- The first case study aimed at decreasing the detrimental emissions of nitric acid production.

- The second case study dealt with the use of waste vegetable oil as a secondary raw material to produce biodiesel, making possible an important economy for diesel production.

In the case of chemical industrial companies, the application of cleaner technologies is one of the key priorities for the future.

Author Contributions: Conceptualization, T.J. and Á.R. Data curation, C.D.S. Formal analysis, C.D.S. Investigation, N.A.-J., V.S. and C.L.P. Methodology, C.L.P. Project administration, E.D. Resources, E.D. Supervision, T.J. and Á.R. Validation, I.C. Visualization, V.S. Writing, original draft, Á.R. Writing, review and editing, I.C.

Funding: This research was funded by GINOP-2.3.2-15-2016-00016, project: Excellence of strategic R+D workshops, University of Pannonia, Hungary.

Conflicts of Interest: The authors declare no conflict of interest.

\section{References}

1. Gavrilescu, M. Cleaner production as a tool for sustainable development. Environ. Eng. Manag. J. 2004, 3, 45-70. [CrossRef]

2. Harja, M.; Ciocinta, R.C.; Cretescu, I.; Apostolescu, M.; Barbuta, M. Crystal growth of calcium carbonate with various morphologies from residual calcium chloride solution. Rev. Chim. 2014, 60, 1025-1031.

3. Nowotny, J.; Dodson, J.; Fiechter, S.; Gür, T.M.; Kennedye, B.; Macyk, W.; Bak, T.; Sigmund, W.; Yamawaki, M.; Rahmana, K.A. Towards global sustainability: Education on environmentally clean energy technologies. Renew. Sustain. Energy Rev. 2018, 81, 2541-2551. [CrossRef]

4. Zhai, Q.; Cao, H.; Zhao, X.; Yuan, C. Cost benefit analysis of using clean energy supplies to reduce greenhouse gas emissions of global automotive manufacturing. Energies 2011, 4, 1478-1494. [CrossRef] 
5. Fisher, B.S.; Nakicenovic, N.; Alfsen, K.; Corfee Morlot, J.; de la Chesnaye, F.; Hourcade, J.-C.; Jiang, K.; Kainuma, M.; La Rovere, E.; Matysek, A.; et al. Issues related to mitigation in the long term context. In Climate Change 2007: Mitigation; Metz, B., Davidson, O.R., Bosch, P.R., Dave, R., Meyer, L.A., Eds.; Contribution of Working Group III to 4th Assessment Report of the Inter-governmental Panel on Climate Change; Cambridge University Press: Cambridge, UK; New York, NY, USA, 2007.

6. Verbruggen, A. Annex I: Glossary. In Climate Change 2007: Mitigation; Metz, B., Davidson, O.R., Bosch, P.R., Dave, R., Meyer, L.A., Eds.; Contribution of Working Group III to 4th Assessment Report of the Inter-governmental Panel on Climate Change; Cambridge University Press: Cambridge, UK; New York, NY, USA, 2007.

7. Fu, Y.; Kok, R.A.W.; Dankbaar, B.; Ligthart, P.E.M.; van Riel, A.C.R. Factors affecting sustainable process technology adoption: A systematic literature review. J. Clean. Prod. 2018, 205, 226-251. [CrossRef]

8. Development and International Co-operation: Environment. Report of the World Commission on Environment and Development: Our Common Future; Note by the Secretary-General, A/42/427; United Nation: Geneva, Switzerland, 1987.

9. Gbededo, M.A.; Liyanage, K. Identification and alignment of the social aspects of sustainable manufacturing with the theory of motivation. Sustainability 2018, 10, 852. [CrossRef]

10. Paulik, K. We have to be sincere to sustainable development. Innotéka 2016, 29, 31-36. (In Hungarian)

11. Vaccaro, L. Green chemistry. Beilstein J. Org. Chem. 2016, 12, 2763-2765. [CrossRef] [PubMed]

12. McKinney, M.L.; Schoch, R.M.; Yonavjak, L.; Mincy, G.A. Environmental Science. Systems and Solutions, 6th ed.; Jones and Bartlett Leaning: Burlington, MA, USA, 2018; ISBN 13-978-1284091700.

13. Van Bueren, E. Environmental Policy. Encyclopædia Britannica, Inc. Available online: https://www. britannica.com/topic/environmental-policy (accessed on 22 April 2018).

14. 2008 Annual Report; Blaszek I., Ed.; Nitrogénmúvek Zrt., Hungary, 2008. Available online: http:/ / www. nitrogen.hu/ (accessed on 1 October 2018).

15. Sustainability, Air Quality, Shell Global. Available online: https://www.shell.com/sustainability/ environment/air-quality.html (accessed on 1 October 2018).

16. Li, Y.; Li, L.; Yu, J. Application of zeolites in sustainable chemistry. Review. Chem. 2017, 3, 928-949. [CrossRef]

17. Robu, B.M.; Caliman, F.A.; Betianu, C.; Gavrilescu, M. Methods and procedures for environmental risk assessment. Environ. Eng. Manag. J. 2007, 6, 573-592. [CrossRef]

18. Cojocaru, C.; Cocârtă, D.M.; Istrate, I.A.; Cretescu, I. Graphical methodology of global pollution index for the environmental impact assessment using two environmental components. Sustainability 2017, 9, 593. [CrossRef]

19. Skalska, K.; Miller, J.S.; Ledakowicz, S. Trends in NOx abatement. Sci. Total Environ. 2010, 408, 3976-3989. [CrossRef] [PubMed]

20. Air Pollution Fact Sheet 2014: Hungary. European Environment Agency, EEA, Copenhagen K, Denmark. 2014. Available online: https:/ / www.eea.europa.eu/themes/air/air-pollution-country-fact-sheets-2014/ hungary-air-pollutant-emissions-country-factsheet (accessed on 9 September 2018).

21. Ministerial Decree 4/2011 (I. 14.) VM on Air Pollution Thresholds and Emissions Ceilings for Located Air Pollutant Point, Hungary. Available online: https://net.jogtar.hu/jogszabaly?docid=a1100004.vm (accessed on 19 April 2018). (In Hungarian)

22. Nitrogen Oxides (NOx) Abatement with Hydrogen Peroxide, USP Technologies, Solutions for a Clean Environment, Canada. Available online: http://www.h2o2.com/industrial/applications.aspx?pid=101 (accessed on 2 June 2018).

23. Ussiri, D.; Lal, R. Soil Emission of Nitrous Oxide and Its Mitigation; Springer: Berlin, Germany, 2013; ISBN 978-94-007-5364-8.

24. Popp, J.; Harangi-Rákos, M.; Gabnai, Z.; Balogh, P.; Antal, G.; Bai, A. Biofuels and their co-products as livestock feed: Global economic and environmental implications. Molecules 2016, 21, 285. [CrossRef] [PubMed]

25. Andrade, J.E.; Perez, A.; Sebastian, P.J.; Eapen, D. Review: A review of bio-diesel production processes. Biomass Bioenergy 2011, 35, 1008-1020. [CrossRef]

26. Lotero, E.; Liu, Y.; Lopez, D.E.; Suwannakarn, K.; Bruce, D.A.; Goodwin, J.G. Synthesis of biodiesel via acid catalysis. Ind. Eng. Chem. 2005, 44, 5353-5363. 
27. Fukuda, H.; Kondo, A.; Noda, H. Biodiesel fuel production by transesterification of oils. J. Biosci. Bioeng. 2001, 92, 405-416. [CrossRef]

28. Hoque, A.; Singh, A.; Chuan, Y.L. Biodiesel from low cost feedstocks: The effects of process parameters on the biodiesel yield. Biomass Bioenergy 2011, 35, 1582-1587. [CrossRef]

29. Gaurav, A.; Flora, T.T.N.; Garry, L. A new green process for biodiesel production from waste oils via catalytic distillation using a solid acid catalyst-Modeling, economic and environmental analysis. Green Energy Environ. 2016, 1, 62-74. [CrossRef]

30. Borges, M.E.; Diaz, L. Recent developments on heterogeneous catalysts for biodiesel production by oil esterification and transesterification reactions: A review. Renew. Sustain. Energy Rev. 2012, 16, 2839-2849. [CrossRef]

31. Vieitez, I.; Da Silva, C.; Alckmin, I.; Borges, R.; Corazza, C.; Oliveira, V.; Grompone, A.; Jachmanián, I. Continuous catalyst-free methanolysis and ethanolysis of soybean oil under supercritical alcohol/water mixtures. Renew. Energy 2010, 35, 1976-1981. [CrossRef]

32. Haas, J.; Foglia, A. Chapter 4: Alternate feedstocks and technologies for biodiesel production. In Biodiesel Handbook; Khothe, G., Van Gerpen, J., Eds.; AOCS Publishing: New York, NY, USA, 2005; ISBN 978-1-4398-2235-7.

33. Shuler, M.L.; Kargi, F. Bioprocess Engineering: Basic Concepts, 2nd ed.; Prentice Hall: Upper Saddle River, NJ, USA, 2002; ISBN 0-13-081908-5.

34. Walsh, B.P.; Og Cusack, D.; O'Sullivan, D.T.J. An industrial water management value system framework development. Sustain. Prod. Consum. 2016, 5, 82-93. [CrossRef]

35. Hevia, M.A.G.; Pérez-Ramírez, J. Assessment of the low-temperature EnviNOx ${ }^{\circledR}$ variant for catalytic $\mathrm{N}_{2} \mathrm{O}$ abatement over steam-activated. Appl. Catal. B-Environ. 2008, 77, 248-254. [CrossRef]

36. Al-Jammal, N.; Al-Hamamre, Z.; Alnaief, M. Manufacturing of zeolite based catalyst from zeolite tuff for biodiesel production from waste sunflower oil. Renew. Energy 2016, 93, 449-459. [CrossRef]

37. Zahan, K.A.; Kano, M. Biodiesel production from palm oil, its by-products, and mill effluent: A review. Energies 2018, 11, 2132. [CrossRef]

38. Biodiesel Production and Distribution U.S. Department of Energy-Energy Efficiency and Renewable Energy. Alternative Fuels Data Center. Available online: https:/ / www.afdc.energy.gov/fuels/biodiesel_production. html (accessed on 2 June 2018).

39. Al-Hamamre, Z.; Yamin, J. Parametric study of the alkali catalyzed transesterification of waste frying oil for biodiesel production. Energ. Convers. Manag. 2014, 79, 246-254. [CrossRef]

40. Leung, C.; Guo, Y. Transesterification of neat and used frying oil: Optimization for biodiesel production. Fuel Process. Technol. 2006, 87, 883-890. [CrossRef]

41. Heck, R.H.; Ferrauto, R.J. Catalytic Air Pollution Control. Commercial Technology; Van Nostrand Reinhold: New York, NY, USA, 1995.

42. EPA. Available and Emerging Technologies for Reducing Greenhouse Gas Emissions from the Nitric Acid Production Industry, Sector Policies and Programs Division Office of Air Quality Planning and Standards; U.S. Environmental Protection Agency: Research Triangle Park, NC, USA, 2010. Available online: https:/ /www.epa.gov/sites/ production/files/2015-12/documents/nitricacid.pdf (accessed on 9 September 2018).

43. Groves, M.; Sasonow, A. Uhde EnviNOx ${ }^{\circledR}$ Technology for $\mathrm{NO}_{\mathrm{X}}$ and $\mathrm{N}_{2} \mathrm{O}$ Abatement. A Contribution to Reducing Emissions from Nitric Acid Plants, Uhde $\mathrm{GmbH}$, Dortmund, Germany. In Proceedings of the 5 th International Symposium on Non- $\mathrm{CO}_{2}$ Greenhouse Gases (NCGG-5), Wageningen, The Netherlands, 30 June-3 July 2009; Available online: https://www.thyssenkrupp-industrial-solutions.com/media/ download_1/nitrates/uhde_publications_pdf_en_15000012.pdf (accessed on 2 June 2018).

44. Lai, S.; She, Y.; Zhan, W.; Guo, Y.; Guo, Y.; Wang, L.; Lu, G. Performance of Fe-ZSM-5 for selective catalytic reduction of $\mathrm{NOx}$ with $\mathrm{NH}_{3}$ : Effect of the atmosphere during the preparation of catalysts. J. Mol. Catal. A-Chem. 2016, 424, 232-240. [CrossRef]

45. Naber, J.E.; deJong, K.P.; Stork, W.H.J.; Kuipers, H.P.C.E.; Post, M.F.M. Industrial applications of zeolite catalysis. In Zeolites and Related Microporous Materials: State of the Art; Weitkamp, J., Karge, H.G., Pfeifer, H., Hölderich, W., Eds.; Elsevier: Amsterdam, The Netherlands, 1994; Volume 84, pp. 2197-2219.

46. Fülöp, T.; Dobos, L.; Császár, V. Nitric acid production at Nitrogénmúvek Company, Hungary. Magy. Kem. Lapja 2013, 6, 178-183. 
47. EnviNOx®-Setting Emission, Standards for Nitric Acid Plants. ThyssenKrupp Uhde, Dortmund, Germany. Available online: www.digitalrefining.com/data/literature/file/386302294.pdf (accessed on 1 October 2018).

48. Goering, C.E.; Fry, B. Engine durability screening test of a diesel oil/soy oil/alcohol microemulsion fuel. J. Am. Oil Chem. Soc. 1984, 61, 1627-1632. [CrossRef]

49. Ayoola, A.A.; Hymore, K.F.; Omonhinmin, C.A. Optimization of biodiesel production from selected waste oils using response surface methodology. Biotechnology 2017, 16, 1-9.

50. Dorodo, W. An alkali-catalyzed transesterification process for high free fatty acid waste oils. Trans. ASAE 2002, 45, 525-529.

51. Eevera, T.; Rajendran, K.; Saradha, S. Biodiesel production process optimization and characterization to assess the suitability of the product for varied environmental conditions. Renew. Energy 2009, 34, 762-765. [CrossRef]

52. Xie, W.; Huang, X.; Li, H. Soybean oil methyl esters preparation using NaX zeolites loaded with $\mathrm{KOH}$ as a heterogeneous catalyst. Bioresource Technol. 2007, 98, 936-939. [CrossRef] [PubMed]

53. Intarapong, P.; Luengnaruemitchai, A.; Jai-In, S. Transesterification of palm oil over $\mathrm{KOH} / \mathrm{NaY}$ zeolite in a packed-bed reactor. IJRER 2011, 4, 271-280.

54. $\mathrm{CO}_{2}$ European Emission Allowances, Markets Insider. Available online: http://markets.businessinsider. com/commodities/co2-emissionsrechte (accessed on 22 April 2018).

55. Liquid Petroleum Products-Fatty Acid Methyl Esters (FAME) for Use in Diesel Engines and Heating Applications-Requirements and Test Methods; German Version EN 14214:2012 + A1:2014. Beuth Verlag GmbH. Available online: https://www.beuth.de/en/standard/din-en-14214/197713876 (accessed on 2 June 2018).

56. American Society for Testing and Materials (ASTM) D6751-02. Standard Specification for Biodiesel Fuel (B100) Blend Stock for Distillate Fuels; ASTM International: West Conshohocken, PA, USA, 2002.

(C) 2018 by the authors. Licensee MDPI, Basel, Switzerland. This article is an open access article distributed under the terms and conditions of the Creative Commons Attribution (CC BY) license (http:/ / creativecommons.org/licenses/by/4.0/). 